\title{
LANDFILL CONSTRUCTION IN RUSSIAN FEDERATION: A STUDY FOR LOCATION AND FINANCIAL DESIGN
}

\author{
Maria A. Belova, \\ Irina O. Churkina \\ Federal Centre for Waste Management, State Committee for Construction \\ and Municipal Complex of Russian Federation, Russia
}

\begin{abstract}
The represented paper describes an original scenario for the landfill construction including the process of decision making upon its location and economic aspects.

The landfill should become a solution for the number of environmental problems as it will result:

- land remediation;

- the cut up in amount of illegal dump areas in the region;

- in the future -creation of a waste sorting plant on the recultivated land;

- other improvements.
\end{abstract}

In the paper the process of decision making upon the location includes three stages and is based on expert analysis of the alternatives using six main criteria. The stages are the following: collection and organizing of the data; development of recommendations; the decision upon the location itself and its fulfillment. The mathematic model is worked out for all the stages which makes it to a certain extend an universal solution.

The study of the economic aspects of the landfill construction is also provided in the paper. It includes analysis of the investment's effectiveness based on certain indexes such as:

- financial effectiveness;

- state budget effectiveness;

- social effectiveness;

- environmental effectiveness; 
- other.

In this part again the original formulas are used for calculation and providing the data for decision making upon the investment needed.

\section{INTRODUCTION}

Out of more than 20 methods of waste disposal used all over the world for economic as well as ecological reasons the most widespread are: waste incineration; anaerobic composting; complex technologies; and, of course, waste disposal to landfills. As a rule, the chosen method depends on economic and demographic situation in the region, accessibility of the raw materials. This defines the governmental policy, administrative and financial instruments used to stimulate the preferred development in the sphere of waste management. But even where complementary disposal technologies are practiced, a landfill is still required and is the backbone of any sustainable disposal system. For Russia, where due to the lack of experience and financial resources open dumpsites come sometimes as the only solution, the introduction of sanitary landfill is an urgent priority.

This paper represents a research, which aims to draw the attention to the problem of landfills in Russia as well as has its practical meaning bringing solutions for a number of problems raised by the process of sanitary landfill construction. The first part provides information about landfills in Russia with their classification, and the scheme of a 'perfect' sanitary landfill. In the second part the process of decision making upon the landfill location, including an original model for the expert ratings evaluation is represented. The third part introduces the ecological aspects of the landfill operation such as ecological monitoring; land remediation; environment improving activities. The forth part is dedicated to the study of the economic aspects of the landfill construction including investment's effectiveness analysis.

\section{LANDFILL}

The most widespread method of waste disposal in Russia is disposal to the landfill. This is the result of the following factors. Methods of waste disposal are chosen basing on technical and economic reports considering local conditions and sanitary terms. The construction of the waste handling plants is economically acceptable in the cities with population of more than 250 thousand people. And even then it is only profitable if local gardening services and farms guarantee the compost consumption. The waste burning plants are possible in the cities with special sanitary terms where this method is the safest. For instance, resort areas as well as in the northem territories. Though costs for industrial methods of waste disposal (such as waste separation, incineration, composting) are considerably higher comparing to costs for disposal to a landfill.

When developing state policy for waste reception and handling it is preferable to control the waste flows, however at this point of the economic growth in Russia it is not possible. In this case the middle-term priority should be given to the method of the waste disposal to the landfills though with the different oriented strategy. Before now the strategy of 
KALMAR ECO-TECH'03

Bioremediation and Leachate Treatment

KALMAR, SWEDEN, November 25-27, 2003

separate landfill for each populated area was used. It resulted in dispersion of waste throughout vast territories, pollution of the environment, and disposal of materials that could be involved in economic turnover to bring value. The alternative to the numerous open dumpsites would be the introduction of sanitary landfill. The usage of the advanced technologies would cut down the area of the land involved and soften the negative environmental affects.

Landfill imply a complex of environmentally safe installations that aim to store, isolate, and render solid waste harmless; it provides protection from the air, soil, and water pollution; prevents from rodents, insects and pathogenic species.

There are several landfill classifications known. The represented one is worked out basing on the amount of the accepted waste, availability of the means for environmental protection and extra means (i.e. waste sorting, composting area and so on).

First category landfills have available:

- technical documentation;

- $\quad$ controlled waste reception;

- $\quad$ preliminary sorting;

- $\quad$ monitoring system;

- $\quad$ full compliance with the sanitary, ecological and esthetic standards;

- $\quad$ working places registration;

- $\quad$ weight control;

- biogas collection;

- filtrate collection and removal;

- correspondence with chosen technology.

Second category landfills have available:

- technical documentation;

- $\quad$ controlled waste reception;

- $\quad$ monitoring system;

- full compliance with the sanitary, ecological and esthetic standards;

- $\quad$ weight control;

- correspondence with chosen technology.

Third category landfills have available:

- technical documentation;

- $\quad$ correspondence with chosen technology;

- general control system.

Forth and fifth category landfills, as a rule, accept small amounts of waste, and are not equipped with safety neither monitoring system. This is the result of the fact that, for the small landfills, the development of the full infrastructure is economically unjustified due to the small working capacities.

The optimum design of a landfill is represented in Appendix 1. 


\section{LANDFILL LOCATION}

The process of decision making upon the landfill location is a crucial part of the whole activity. As a rule, there are several areas where the construction could take place. While developing a plan for the landfill, this situation is suggested as a point of countdown.

The ecological criteria used in the process of decision making include:

- distance from the landfill to the living areas, water sources, resorts, and arable lands;

- $\quad$ presence of ground and coastal waters, national parks;

- geological and hydro-geological conditions of the considered area;

- $\quad$ risk of floods, ground settling, landslide, and caving-in in the area;

- $\quad$ degree of environmental protection from the state.

Those criteria are used to determine the areas where the landfill could be located. The analysis of choices is to be made on the next stage.

Areas prohibited for the landfill construction:

1. Sanitary protected zones of water and mineral sources;

2. Protected resort areas;

3. Territories with open cracked grounds;

4. Territories with open water-bearing grounds;

5. Territories with water springs;

6. Places of public rest and rest homes;

7. Swamp areas of more than $1 \mathrm{~m}$ depth;

8. Areas which are closer than $500 \mathrm{~m}$ to the living houses or drinking water sources;

9. Areas which are closer than $500 \mathrm{~m}$ to the airports;

10. Areas of urban or rural settlements;

11. Lands that contain raw materials and works are undertaken in the cases when there is a risk to the safety of the works or pollution.

Areas not recommended for the landfill construction:

1. Territories with the filtration index higher than $10^{-5} \mathrm{sm} / \mathrm{sec}$;

2. Territories where the level of the ground waters is less than $1 \mathrm{~m}$ from the surface;

3. Areas with possible spring floods;

4. Areas with preserved forests;

5. Areas with water sources situated closer than $500 \mathrm{~m}$;

6. Privately owned territories due to the ransom;

Areas that are favorable for the landfill construction:

1. Territories with clay or hard loamy soils with the ground waters located deeper than 2 meters;

2. Territories that are situated in the economically justified distance from the center of waste collection (not further than $15 \mathrm{~km}$ ); 
KALMAR ECO-TECH'03

Bioremediation and Leachate Treatment

KALMAR, SWEDEN, November 25-27, 2003

3. Total area of the land provides conditions for the long term operation of the landfill as well as future extension;

4. Areas of the lowlands as well as quarry and sandpit cavities;

5. Leeward territories considering location of residential areas;

6. Territories with developed road infrastructure which would ease transportation of the solid waste and landfill production (recyclable materials, compost);

7. Areas located near existing of projected engineering communications of electric, water or heating supply, sewerage or telephone station;

8. Partly assimilated areas with green plantations or ground embankments within $500 \mathrm{~m}$.

The decision upon the landfill location is to be made by authorized institutions taking into account expert evaluations. The represented model includes:

Three grounds appropriate for solid waste landfill construction - A, B, C;

Six expert groups that include representatives from: Center for architecture and planning; Architecture and building deparment; Department for environmental protection; Department for sanitary control; Hydro-geological center; Federal Center for Waste Management - \#1,2,3,4,5,6.

Stages of the process include:

1. Data processing;

2. Drawing up of recommendations;

3. Decision making upon the location.

When organizing the process of decision making upon the landfill location it is necessary to remember that the represented situation belongs to the class of multicriteria problems (three altemative, six criteria groups). This kind of problems is to be solved with certain adaptation along the process. It means that the procedures and mechanisms of decision making should be corrected during the working period. This fact prevents from drawing up an absolutely universal model: each time existing experience and data bring their corrections. In practice, the introduced model could be used as a basis (Appendix 2).

Documentation essential for solid waste landfill construction include:

- hydro-geological conclusion upon suitability of the territory for a landfill and recommendations for engineering protection of the environment;

- $\quad$ conclusion upon compliance of the territory with sanitary standards;

- permission from the institutions for environmental protection;

- $\quad$ permission from the authorized body in the field of waste management (Federal Center for Waste Management).

Decision upon landfill location is to be made by a group of specialists that include representatives of:

Federal Estate Committee;

Architecture and Building Committee;

Municipal Services; 
KALMAR ECO-TECH'03

Bioremediation and Leachate Treatment

KALMAR, SWEDEN, November 25-27, 2003

- $\quad$ Sanitary Services;

- Department for environmental protection;

- $\quad$ Geological Committee;

- $\quad$ Federal Center for Waste Management;

- $\quad$ Center for architecture and planning;

- $\quad$ other institutions that provide competent conclusions required by the municipal governing bodies.

The process of decision making upon the landfill location is very important on the stage of landfill projecting. Implementation of the planning, operation and remediation rules leads to the significant reduction of negative effect on the environment and public health. In addition, a number of activities aiming to protect environment should take place. Therefore special attention deserves landfill ecology.

\section{LANDFILL ECOLOGY}

Complex of the necessary installations for a landfill being a mean of environmental protection is introduced in the following legal documents: Instructions for solid waste landfill design, operation and remediation, SanPiN 2.1.7.722-98; Sanitary orders for landfill structure and content, SP 2.1.7.1038-1. The protection measures include ecological monitoring, land remediation, activities aiming to lower negative effects on the environment, general monitoring system. Though being listed, those measures have no precise description in the legal documents neither in landfill projects. This explains special attention given to landfill ecology in presented study.

\section{ECOLOGICAL MONITORING PROGRAM}

On the stage of landfill projecting it is crucial to work out such issues as:

- $\quad$ ecological condition of the territory up to date;

- $\quad$ forecast of possible negative effects on the environment.

The landfill project should include the results of geological and hydro-geological studies, the results of ground components (soils, grounds, water sources) analysis, statistic data on medical, bio, and sanitary research along with other important information. Geographic data should include a plan of ecological condition of the territory up to date as well as forecasted condition, schemes of the territories affected by a landfill considering possible migration, accumulation and production of the polluting products, and so on.

The forecasted ecological plan should include:

- possible changes of the landscape (soils degradation, transformation of plantations, decrease of the forest areas, etc.);

- $\quad$ expected changes of separate components of the environment (change in ground waters level, soil salting, floods, etc.);

- $\quad$ expected dynamics for dispersion of polluting products;

- $\quad$ changes in evaluation of ecological well-being of the territory. 


\section{LAND REMEDIATION}

Situations when designed capacity is exhausted or the state is anti sanitary and reconstruction is impossible require closure of a landfill. The main condition then is that the area will exist during unlimited period of time as part of the landscape or recreation area totally safe for the environment as well as public health.

Land remediation includes a complex of works aiming to restore efficiency and economic value of the territories along with improvement of the environment. The territories of closed landfills are likely to be used for agricultural, plantation, and recreational purposes.

There are two stages of land remediation: technical and biological. The technical stage includes landfill mass study and its influence on the environment, preparation of the territory for further usage (creation of multifunctional cover; planning and building up slopes; developing, transportation and creation of technological layers and potentially fertile soils; construction of the roads and other installations).

Biological stage of the land remediation is aimed to restore the territories for further usage.

\section{ENVIRONMENT PROTECTION}

Activities aiming to lower negative effects on the environment include creation of isolating coat on the landfill base and development of the system for filtrate collection and rendering harmless.

For the grounds with filtrate index higher than $10^{-9} \mathrm{~m} / \mathrm{sec}$ it is necessary to provide artificial waterproof screen. For this purpose there are several alternatives to choose from:

1. Clay screen minimum $0.5 \mathrm{~m}$ thick. The screen is to be covered with safety layer made of local soil 0.2-0.5 m thick;

2. Ground screen processed with organic astringents or oil-refining waste products $0.2-0.4 \mathrm{~m}$ thick;

3. Double layer latex screen. Over the ground layer $0.3 \mathrm{~m}$ thick goes latex screen, then $0.4 \mathrm{~m}$ of sand and second latex layer with safety ground layer $0.5 \mathrm{~m}$ thick on top;

4. Screen made of polyethylene. The screen consists of sandy ground base, two layers of polyethylene with drainage sand layer in between and top safety layer made of sandy ground.

The introduced system for filtrate collection and rendering harmless consists of hidden drainage (perforated pipes), which is located in the landfill base and open ponds near the slopes at the landfill base. The system also includes filtrate-accumulating ponds in order to remove the top amounts. 
KALMAR ECO-TECH'03

Bioremediation and Leachate Treatment

KALMAR, SWEDEN, November 25-27, 2003

The process of rendering filtrate harmless is undertaken at the local refinery stations. When the municipal stations are involved, the substance is to be transported using hermetic pipelines.

\section{GENERAL MONITORING SYSTEM}

General monitoring system includes the following issues:

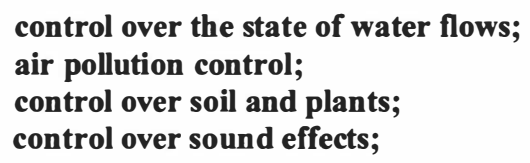

In order to check the state of waters it is necessary to plan prospect-holes in the upper and lower lands of the landfill depending on ground water flows. The prospect-holes are to be made according to the rules of hydro-geological services and sanitary committee and locate within 50-100 m distance from the landfill. Collecting water samples should be examined in order to find out the amount of contained ammonium hydrates, nitrites, nitrates, hydrocarbonates, calcium, chlorides, iron, sulfates, lithium, organic carbon, $\mathrm{pH}$, magnum, cadmium, chrome, cyanides, lead, quicksilver, arsenic, copper, cadmium, barium, destructive leftover and other. In addition to ground waters control, samples of open waters should be taken. The samples are to be examined for helminthological, bacteriological, and sanitary indexes.

In order to realize air pollution control it is necessary to carry out regular analysis of atmospheric air samples above the exhausted areas and their border lines. The analysis should determine the amount of hazardous gaseous products of decay in the air: methane, hydrogen sulfide, carbon monoxide, benzyl, etc.

\section{LANDFILL ECONOMICS}

Economic aspects of landfill construction affect the whole arrangement and it is simply irresponsibly not to consider them. This part provides information about the situations when the landfill construction is justified, along with landfill investment efficiency study.

When planning a landfill construction it is crucial to consider whether it would be economically justified or not. It is calculated that building up of separate landfill for urban or rural settlements with population smaller than 3 thousand is economically unjustified. Larger landfills provide economy of scale, when the equipment is used more efficiently and operation costs per unit are much lower. Thus creation of a landfill for a group of smaller settlements is recommended. In this case the solutions of technical problems would be similar to those of a landfill for a town with $10000-50000$ people. Difficulties arise only on the stage of decision making upon landfill location and while solving transportation problems.

A landfill should be planned for a long-term operation due to the significant construction and operation costs. It should be taken into account that minimum period of operation is 25 years. 
Investment effectiveness is evaluated by following indexes:

- $\quad$ financial effectiveness index which shows profitability of investment;

- $\quad$ budget effectiveness index which shows benefits measured in the amount of taxes brought by the project;

- $\quad$ economic effectiveness index which considers costs involved;

- social effectiveness index--creation of new working places for the population;

- $\quad$ ecological effectiveness.

On the stage of landfill planning it is rational to use average figures. Average amounts of annual waste flows and the tariffs for solid waste disposal data enables to calculate the annual revenue and draw up the evaluation of the investment necessary to make the project profitable.

For this purpose the following formulas are used:

$C+L \times K \Subset D$

where $C$ - annual operation costs;

$K$ - capital investments;

$D$ - annual revenue.

$L=\frac{Q}{1-(1+Q)^{-p}}$

$Q=d+i$

where $d$ - annual discounting average;

$i$ - constant inflation average;

$\mathrm{p}$ - expected operation period.

Operation costs are calculated basing on energy expenditures, number of personnel, and transportation costs data. Taking into account taxes, flexible tariffs and possible commercial use of the recyclable materials will result in correction of the amount of investments needed.

It is obvious that the effective operation of a sanitary landfill is more economically justified than existing system of dumping areas and uncontrolled landfilling. It also improves environment and brings social bonuses. Encouraging landfill investments and sustainable operations is not only crucial for our region to benefit. As the environmental damages tend to spillover into neighboring municipalities and regions, or into underlying groundwater resources sanitary landfill construction is a subject of federal control and intemational cooperation. 
Appendix 1 .

\section{THE OPTIMUM DESIGN OF A LANDFILL}

\section{FRONT VIEW}

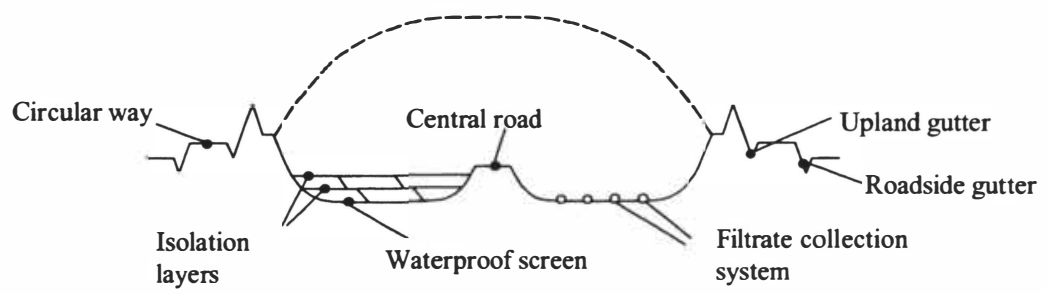

\section{EXPLICATION}

1. Waste sorting station;

2. Waste burning station;

3. Weight control;

4. Administrative and additional buildings;

5. Parking lot for transport used within the landfill area and special transport, washing station;

6. Entrance to the landfill;

7. Sanitary gutter;

8. Composting areas;

9. Biogas collection and disposal stations;

10. Biogas collection system;

11. Filtrate collection system;

12. Filtrate collector;

13. Pumping station;

14. System of filtrate retum to the landfill;

15. Fence.

Monitoring system for atmospheric air, soil and water resources is situated along the fence as well as above exhausted areas. 
KALMAR ECO-TECH'03

Bioremediation and Leachate Treatment

KALMAR, SWEDEN, November 25-27, 2003

PLAN

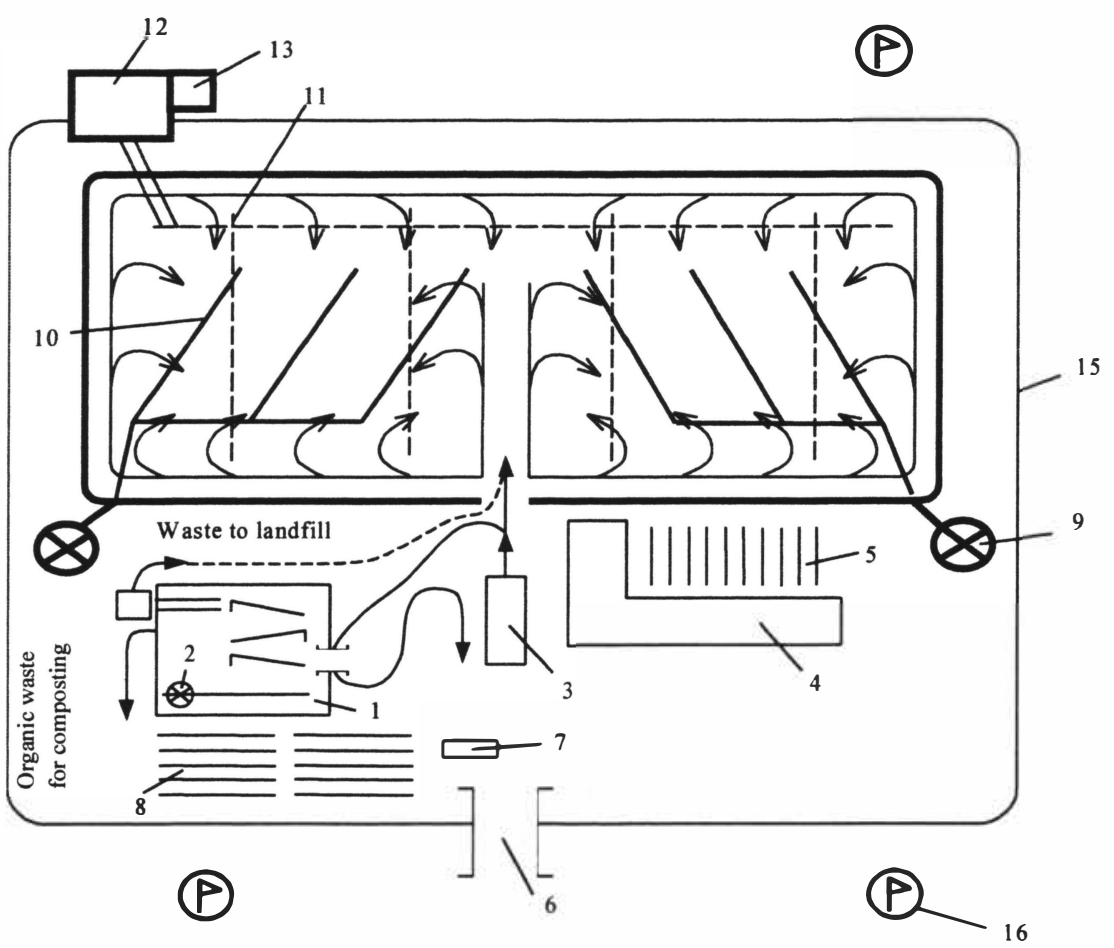

Appendix 2.

On the first stage the following formalized table is suggested for data processing:

\begin{tabular}{|c|c|c|c|c|c|c|}
\hline \multirow{2}{*}{ Alternatives } & \multicolumn{6}{|c|}{ Expert groups } \\
\hline & $\# 1$ & $\# 2$ & $\# 3$ & $\# 4$ & $\# 5$ & $\# 6$ \\
\hline A & $\overline{\mathrm{AI}}$ & $\overline{A 2}$ & $\overline{\mathbf{A 3}}$ & $\overline{\mathrm{A4}}$ & $\overline{A S}$ & $\overline{A 6}$ \\
\hline B & B1 & B2 & B3 & B4 & B5 & B6 \\
\hline C & CI & $\mathrm{C} 2$ & $\mathrm{C3}$ & C4 & C5 & C6 \\
\hline
\end{tabular}

Where:

A, B, C-alternatives*);

\#1,2,3,4,5, 6 - expert groups**);

A1-6, B1-6, C1-60- estimations of the alternatives***)

*) Each area possibly used for a landfill is represented as an alternative. Information should include materials correspondent with demands of each expert group.

**) Expert groups include representatives of the institutions in charge of decision making upon landfill location.

***) Estimation of the alternatives is made by expert groups and is represented by documentation including (a) qualitative evaluation of the altemative considering its suitability for the project; (b) evaluation basis; (c) defiects of given alternative. 